\begin{tabular}{ccc|} 
ISSN = 1980-993X - doi:10.4136/1980-993X \\
www.ambi-agua.net \\
E-mail: ambi-agua@agro.unitau.br \\
Tel.: (12) 3625-4212
\end{tabular}

\title{
Nitrogen dynamics in soils cultivated with maize and fertilized with pig slurry
}

\author{
(http://dx.doi.org/10.4136/ambi-agua.782)
}

\author{
Denise de Freitas Silva ${ }^{1}$; Camilo L. T. Andrade ${ }^{1}$; Álvaro Vilela Resende ${ }^{1}$; Clério \\ Hickmann²; Tales Antônio Amaral $^{3}$; Maria Emília Borges Alves ${ }^{4}$ \\ ${ }^{1}$ Embrapa Maize and Sorghum, Sete Lagoas, MG \\ e-mail: denisefreitassilva@ oi.com.br; camilo@cnpms.embrapa.br; \\ alvaro@cnpms.embrapa.br; \\ ${ }^{2}$ Universidade Federal de Lavras, Lavras, MG \\ e-mail: clerioh@gmail.com; \\ ${ }^{3}$ Universidade Federal de Pelotas, Pelotas, RS \\ e-mail: tales_aamaral@yahoo.com.br; \\ ${ }^{4}$ National Agriculture Confederation, Brasília, DF \\ e-mail: mebalves@hotmail.com
}

\begin{abstract}
The proper disposal of pig manure is of great importance because, when mishandled, it can contaminate water resources. This study aimed to evaluate the nitrogen dynamics in a Cerrado Oxisol and its absorption, over time, by a maize crop managed with pig slurry associated with mineral fertilization (N P K). The study was conducted at a private farm, in the region of Sete Lagoas, Minas Gerais, Brazil. The maize crop was able to recover $62 \%$ of the mineral nitrogen that entered the soil-plant system, while $9 \%$ leached as nitrate and, to a lesser amount, as ammonium. The maximum average content of nitrate and ammonium of 92 $\mathrm{kg} \mathrm{ha}^{-1}$ and $43 \mathrm{~kg} \mathrm{ha}^{-1}$, respectively, was observed in the 0 to $0.3 \mathrm{~m}$ soil layer during the early crop development stage. A minimum content of $5.8 \mathrm{~kg} \mathrm{ha}^{-1}$ of nitrate and $9.0 \mathrm{~kg} \mathrm{ha}^{-1}$ of ammonium, respectively, was measured at the end of the cycle. In addition, the nitrate content at that soil layer, at the end of the maize cycle, remained below the values measured at the native Cerrado, indicating that the agricultural use of the land poses no additional risk to the nitrate accumulation and leaching into the soil profile.
\end{abstract}

Keywords: environmental contamination; leaching; maize yield; Zea mays L..

\section{Dinâmica do nitrogênio em Latossolo cultivado com milho e adubado com dejetos líquidos de suínos}

\section{RESUMO}

A destinação adequada dos dejetos suínos é de grande relevância, pois quando mal manejada, pode provocar contaminação de recursos hídricos. Este trabalho teve como objetivo avaliar a dinâmica do nitrogênio no perfil de um Latossolo sob Cerrado e a sua absorção, ao longo do tempo, pela cultura do milho, manejada com uso de dejetos líquidos de suínos, associado à adubação mineral (N P K). O estudo foi realizado em uma propriedade particular da região de Sete Lagoas, MG, Brasil. A cultura recuperou $62 \%$ do nitrogênio mineral que entrou no sistema solo-planta, enquanto $9 \%$ lixiviou na forma de nitrato e, em menor quantidade, na forma de amônio. Teores médios máximos de nitrato e amônio de $92 \mathrm{~kg} \mathrm{ha}^{-1} \mathrm{e}$ de $43 \mathrm{~kg} \mathrm{ha}^{-1}$, respectivamente, foram observados na camada 0-0,3 $\mathrm{m}$ no início do 
SILVA, D. F; ANDRADE, C. L.T.; RESENDE, A. V.; HICKMANN, C.; AMARAL, T. A.; ALVES, M. E. B. Nitrogen dynamics in soils cultivated with maize and fertilized with pig slurry. Ambi-Agua, Taubaté, v. 7, n. 1, p. 9-23, 2012. (http://dx.doi.org/10.4136/ambi-agua.782)

desenvolvimento da cultura. Conteúdos mínimos de $5,8 \mathrm{~kg} \mathrm{ha}^{-1}$ de nitrato e de $9,0 \mathrm{~kg} \mathrm{ha}^{-1}$ de amônio, foram medidos no final do ciclo. Além do mais, os teores de nitrato naquela camada, ao final do ciclo da cultura do milho, mantiveram-se abaixo dos valores observados do Cerrado nativo, indicando que o uso agronômico da terra não ofereceu risco adicional de acúmulo e lixiviação de nitrato no perfil do solo.

Palavras-chave: contaminação ambiental; lixiviação; produtividade de milho; Zea mays L..

\section{INTRODUCTION}

Brazilian swine production has risen sharply in recent decades, as a result of effective use of technologies associated with animal breeding, balanced feeding, and management in various forms of animal confinement. As a result, productivity has increased, resulting in large concentrations of animals per unit area, along with large accumulations of organic wastes. These are of great importance from a technical and environmental point of view since, when mishandled, animal manure can cause water resource contamination (Seidel et al., 2010). Recently, the Brazilian Ministry of Agriculture launched an incentive program for lowcarbon agriculture, with proper treatment and disposal of pig slurry as one of its priorities (Brasil, 2010).

The use of pig slurry as fertilizer is one of the correct destinations of this waste, because it allows nutrient cycling within the production unit, making the system sustainable. The fertilizer potential of pig slurry is often attributed to its different concentrations and amounts of nutrients, especially nitrogen (Ceretta, 2003; Giacomini and Aita, 2008; Giacomini et al., 2009). This makes it a promising fertilization alternative for crops, such as maize, that demand large amounts of nitrogen. However, it should be used with caution, as factors related to the imbalance between soil nutrient availability and plant demand can cause some ionselective accumulation in the soil (Ceretta, 2003). The rate of slurry to be applied to the field depends on the pig slurry's fertilizer value, on the soil characteristics and chemical tests, and on crop nutrient requirements. However, when there has been no previous chemical analysis of the manure, Konsen (2003) recommends using 40 to $90 \mathrm{~m}^{3} \mathrm{ha}^{-1}$ for conventionally managed maize, and 50 to $100 \mathrm{~m}^{3} \mathrm{ha}^{-1}$ for the no-tillage maize grown in Cerrado soils.

In Brazil, information about soil organic matter content and previous crop biomass have been used as the main indication of nitrogen release from the soil during the crop cycle, assuming that the $\mathrm{N}$ present in soil organic matter and in the previous crop biomass will be mineralized in time to be absorbed by the current crop (Amado et al., 2002).

Nitrate $\left(\mathrm{NO}_{3}{ }^{-}\right)$leaching is considered the main loss of $\mathrm{N}$ in cultivated soils, and it is directly influenced by the factors that determine the soil water flow and the $\mathrm{NO}_{3}{ }^{-}$ concentration in the soil solution (White, 1987). The greater the soil-water storage capacity, the lower the water's deep percolation and, therefore, the lower the $\mathrm{NO}_{3}{ }^{-}$leaching (Bortolini et al., 2000).

Another important factor in the dynamics of nutrients is related to the soil's physicochemical properties, which affect the balance of charges and the specific surface of clay particles in the subsurface soil layers. The adsorption of $\mathrm{N}^{-N_{3}}{ }^{-}$in variable-charged soils tends to increase with depth. This phenomenon is associated with the increased number of positive electrical charges in this direction (Dynia et al., 2006), a typical characteristic of the highly weathered Oxisols that dominate the Brazilian Cerrado region. Oliveira et al. (2000) observed that the adsorption of $\mathrm{N}$ species increased with soil profile depth and was higher in soils under native Cerrado vegetation as compared to cultivated soils.

Some studies were conducted to try to predict nitrogen supplement requirements for some crops, taking into consideration the nitrate and mineral nitrogen contents in the soil 
SILVA, D. F; ANDRADE, C. L.T.; RESENDE, A. V.; HICKMANN, C.; AMARAL, T. A.; ALVES, M. E. B. Nitrogen dynamics in soils cultivated with maize and fertilized with pig slurry. Ambi-Agua, Taubaté, v. 7, n. 1, p. 9-23, 2012. (http://dx.doi.org/10.4136/ambi-agua.782)

before and during the crop cycle. Some soil tests have been developed to guide the nitrogen recommendations for maize. These tests, discussed in detail by Rambo et al. (2004), are divided into a pre-sowing test (TPS), a pre-application of nitrogen test (TPNC), and a postharvest test (TPC). The critical $\mathrm{N}_{-\mathrm{NO}_{3}}{ }^{-}$levels in soil, above which it is considered that there is excess $\mathrm{N}$, are between 15 to $30 \mathrm{mgkg}^{-1}$ (Rambo et al., 2007).

In this sense, the objective of this paper was to evaluate soil mineral nitrogen dynamics in an Oxisol, and its absorption by a maize crop managed with pig slurry associated with conventional mineral fertilization.

\section{MATERIALS AND METHODS}

The study was conducted at a farm located in the region of Sete Lagoas, MG, Brazil $\left(19^{\circ}\right.$ 23' 19" South, 44 32' 33" West, elevation $686 \mathrm{~m})$. The local climate is classified by Köppen as Aw, tropical savanna, with dry winters and an average temperature in the coldest month greater than $18^{\circ} \mathrm{C}$. The average annual temperature and precipitation in the last 60 years were, respectively, $22.1{ }^{\circ} \mathrm{C}$ and $1300 \mathrm{~mm}$, with a well-defined rainy season. A maximum rainfall average of $290 \mathrm{~mm}$ is observed in December, and a minimum average of $8 \mathrm{~mm}$ in August. The soil of the study area is classified as a typical Oxisol, whose major attributes are shown in Table 1.

Table 1. Chemical properties for different soil layers of the study area ${ }^{1}$.

\begin{tabular}{|c|c|c|c|c|c|c|c|c|c|c|}
\hline \multirow{2}{*}{$\begin{array}{c}\text { Layer } \\
(\mathrm{m})\end{array}$} & \multirow{2}{*}{$\begin{array}{r}\mathbf{p H} \\
\left(\mathrm{H}_{2} \mathrm{O}\right) \\
\end{array}$} & $\mathbf{H}+\mathbf{A l}$ & Al & $\mathrm{Ca}$ & Mg & $\mathrm{CTC}_{\text {pot }}$ & $\mathbf{K}$ & $\mathbf{P}$ & \multirow{2}{*}{$\begin{array}{c}\mathbf{M O} \\
\left(\operatorname{dagkg}^{-1}\right)\end{array}$} & \multirow{2}{*}{$\begin{array}{l}\mathbf{V} \\
(\%)\end{array}$} \\
\hline & & \multicolumn{5}{|c|}{$\left(\mathrm{cmol}_{\mathrm{c}} \mathrm{dm}^{-3}\right)$} & \multicolumn{2}{|c|}{$\left(\mathrm{mgdm}^{-3}\right)$} & & \\
\hline $0-0.15$ & 5.6 & 4.98 & 0.00 & 3.31 & 1.02 & 10.08 & 300 & 64 & 3.19 & 51 \\
\hline $0.15-0.30$ & 5.5 & 4.36 & 0.00 & 1.95 & 0.54 & 7.30 & 174 & 12 & 1.59 & 40 \\
\hline $0.30-0.45$ & 5.3 & 3.20 & 0.12 & 1.22 & 0.38 & 5.02 & 85 & 2 & 1.64 & 36 \\
\hline $0.45-0.60$ & 5.4 & 2.96 & 0.12 & 0.98 & 0.33 & 4.45 & 71 & 2 & 1.39 & 34 \\
\hline $0.60-0.90$ & 4.8 & 2.93 & 0.12 & 0.42 & 0.16 & 3.59 & 31 & 1 & 1.07 & 18 \\
\hline $0.90-1.20$ & 4.6 & 2.93 & 0.12 & 0.29 & 0.10 & 3.37 & 21 & 1 & 0.86 & 13 \\
\hline
\end{tabular}

${ }^{1}$ Methods of soil analysis described in Embrapa (1997).

The study area has been cultivated for more than 20 years. In the first 10 years, soil management was based on conventional tillage; later the no-till system was adopted. In the last seven years, due to the occurrence of frequent dry spells, a center pivot irrigation system has been used to irrigate an area of 90 ha. Pig slurry, in combination with mineral fertilizer, has been used in the last seven years as a source of nutrients for maize.

In this study, a 0.5 ha area was randomly selected inside the 90 ha center pivot area. This area was divided into four plots, each plot being considered a replication. Each plot consisted of eight maize rows $10 \mathrm{~m}$ long and $0.68 \mathrm{~m}$ apart. The six central rows were tagged for the final evaluation.

The farmer has adopted an intensive no-till management system, with successive maize sowings, with no crop rotation. In 2008, the single-cross maize hybrid DKB 390YG was sown on October $25^{\text {th }}$. Emergence occurred nine days after sowing (DAS), silking at 63 DAS, and physiological maturity at 133 DAS. Harvest was performed at 136 DAS. Fertilization consisted of $70 \mathrm{~m}^{3} \mathrm{ha}^{-1}$ of pig slurry, biologically stabilized in a bioreactor, applied 17 days before sowing. The pig slurry remained in the bioreactor for 35 days, and was subsequently stored in lagoons until distribution on the plantations. The stable slurry was applied in the 
field by using a mechanical spreader. This fertilizer was supplemented with $350 \mathrm{kgha}^{-1}$ of the formula 09-33-12 (NPK), placed deeper than the seeds, during the sowing operation. Additionally, $150 \mathrm{kgha}^{-1}$ of urea was side-dressed at 12 and 25 DAS. The chemical composition of the stable pig slurry used is presented in Table 2.

Since sowing was done during the rainy season in Brazil, only two irrigations were applied early in the maize crop cycle. Irrigation management was based on the farm manager's previous experience, and there has been no interference in this procedure.

In order to monitor nitrate and ammonium concentrations along the crop cycle, the soil was sampled using a Dutch auger at the 0 to $0.3 \mathrm{~m}, 0.3$ to $0.6 \mathrm{~m}$, and 0.6 to $1.2 \mathrm{~m}$ layers. No sampling was performed at the 0.60 to $1.2 \mathrm{~m}$ layer on $11,19,26$ DAS because we did not consider it relevant at this early crop stage. The soil was also sampled once, at the same depths, inside the adjacent reserve of Cerrado. This way, we had a baseline to compare with the cultivated area.

Table 2. Nutrient content of pig slurry after being stabilized in a bioreactor for 35 days and just prior to field application ${ }^{1}$.

\begin{tabular}{c|c}
\hline Components & Content $\left(\mathbf{m g L}^{-\mathbf{1}}\right)$ \\
\hline $\mathrm{N}_{\text {total }}{ }^{+}$ & 1179.18 \\
$\mathrm{~N}^{+} \mathrm{NH}_{4}{ }^{-}$ & 957.35 \\
$\mathrm{~N}_{3} \mathrm{NO}^{-}$ & 2.80 \\
$\mathrm{P}$ & 188.35 \\
$\mathrm{~K}$ & 581.88 \\
$\mathrm{Ca}$ & 152.40 \\
$\mathrm{Mg}$ & 72.92 \\
$\mathrm{Zn}$ & 20.30 \\
$\mathrm{Fe}$ & 17.73 \\
$\mathrm{Cu}$ & 8.92 \\
$\mathrm{Mn}$ & 3.21 \\
$\mathrm{Na}$ & 140.00 \\
\hline
\end{tabular}

${ }^{1}$ Methods of analysis described in Embrapa (1997).

The samples were collected in between the crop rows, in three randomly dug holes inside the plot. In the native Cerrado the soil samples were collected at three representative points of the area. The three samples were mixed together to produce one composed representative

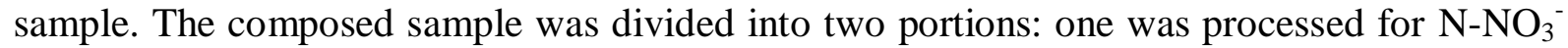
and $\mathrm{N}-\mathrm{NH}_{4}{ }^{+}$determinations, and the other for soil fertility analysis. All methods of analysis are described in EMBRAPA (1997).

The Kjeldahl distillation method was used for soil $\mathrm{N}-\mathrm{NH}_{4}{ }^{+}$and $\mathrm{N}-\mathrm{NO}_{3}{ }^{-}$determinations. Nitrogen extraction was performed with a $\mathrm{KCl} 2 \mathrm{molL}^{-1}$ solution. A $10 \mathrm{~mL}$ extract sample was used in the distillation process. In the first distillation for $\mathrm{N}^{-\mathrm{NH}_{4}}{ }^{+}$determination, $\mathrm{MgO}$ was added and, in the second distillation of the same sample, the Devarda alloy was added for $\mathrm{NO}_{3}{ }^{-}$determination, with subsequent quantification by titration with $\mathrm{H}_{2} \mathrm{SO}_{4}$ (Nogueira and Souza, 2005). The mineral-N content was calculated as the sum of the $\mathrm{N}_{-} \mathrm{NO}_{3}{ }^{-}$and $\mathrm{N}-\mathrm{NH}_{4}{ }^{+}$ content.

The mineral nitrogen dynamics in the 0 to $0.60 \mathrm{~m}$ soil layer was evaluated along the crop cycle. As input to the system, we considered the sum of the mineral nitrogen present in pig slurry, the mineral fertilizer applied at sowing, side-dressings performed, the nitrogen present in the existing soil surface mulching before planting, and the existing soil mineral nitrogen 
SILVA, D. F; ANDRADE, C. L.T.; RESENDE, A. V.; HICKMANN, C.; AMARAL, T. A.; ALVES, M. E. B. Nitrogen dynamics in soils cultivated with maize and fertilized with pig slurry. Ambi-Agua, Taubaté, v. 7, n. 1, p. 9-23, 2012. (http://dx.doi.org/10.4136/ambi-agua.782)

(nitrate plus ammonium) prior to the pig manure application. As output, we considered the nitrogen accumulated in the crop aboveground biomass, the mineral nitrogen presented in the 0 to $0.60 \mathrm{~m}$ soil layer at the end of the crop cycle, and the nitrogen leached below the rooting system, which was regarded as the mineral nitrogen presented in the 0.60 to $1.20 \mathrm{~m}$ soil layer. The amount of $\mathrm{N}$ presented in the roots was neglected.

Maize crop aboveground biomass was sampled at different crop stages and processed separately as leaves, stem + tassel, husks, cobs, and grains. Samples were then taken to an oven, at $65^{\circ} \mathrm{C}$, for dry mass determination. Later on, the maize plant components were milled and stored for subsequent nutrient analysis. Plant tissue nitrogen concentration was determined by the Dumas method, as described by Ribeiro (2010). With dry mass and nutrient concentration data, maize crop element absorption at different stages was estimated. At the end of the crop cycle, grain yield and yield components were evaluated.

Maize crop rooting system distribution was also evaluated. Undisturbed soil samples with $0.0013 \mathrm{~m}^{3}$ thickness were collected at the same soil profile layers used for soil characterization. Samples were washed inside a small mesh sieve to separate roots from soil material. Clean roots were stored in flasks containing a $70 \%$ ethanol solution in order to prevent tissue dehydration. Root length, volume, and diameter were estimated by using the WinRhizo, which consists of a professional scanner model Epson 10000 XL, equipped with an additional light unit (TPU). The procedures for determining the volume of roots per volume of soil are described in Costa et al. (2002).

The data on $\mathrm{N}-\mathrm{NH}_{4}{ }^{+}, \mathrm{N}_{-} \mathrm{NO}_{3}{ }^{-}$and on $\mathrm{N}$-mineral were submitted to analysis of variance using the SISVAR (Ferreira, 2000) program. The effect of time (days after sowing, DAS) on soil ammonium and nitrate content was evaluated using the F test. When significant effects were found, linear equations were fit to soil nitrate and ammonium content as a function of DAS. Regression models were adjusted using the t test with up to $10 \%$ probability. We were not interested in fitting a model that perfectly described the nitrate and ammonium dynamics, but in checking the trend in these ions' behavior, over time, for different soil profile layers, in order to assess their mobility. The soil nitrate and ammonium content data under the Cerrado vegetation were compared with those observed along the crop cycle of the cultivated area.

Soil-water content at different soil profile layers was monitored along the crop cycle. Soil-water storage was calculated to a depth of $0.60 \mathrm{~m}$. Soil material was submitted to laboratory analysis to determine the upper and lower limits of available water so that total soil-water availability to plants could be calculated. The rainfall data were monitored using an automatic weather station installed at the site.

Charts were plotted to facilitate interpretation of data on plant nitrogen absorption and on the dynamics of water, nitrate, and ammonium in the soil. Rooting system distribution was evaluated and inferences were made regarding nitrogen leaching.

\section{RESULTS AND DISCUSSION}

It was observed that the maize rooting system had grown up to $1.20 \mathrm{~m}$ deep (Figure 1). However, the largest concentration of roots per unit of soil volume was observed in the 0 to 0.6 m layer, which is consistent with observations made by Ivo and Mielniczuk (1999). Based on these findings, observed soil-water storage and lab-determined soil-water retention limits were calculated for that layer and plotted versus time. Moreover, the nitrogen amounts presented in the 0.6 to $1.20 \mathrm{~m}$ layer were considered prone to leaching.

We observed that, due to rain and irrigation, soil-water storage in the 0 to $0.60 \mathrm{~m}$ layer remained consistently above $50 \%$ of soil available (Figure 2) water and, therefore, the crop did not suffer severe water stress. 
SILVA, D. F; ANDRADE, C. L.T.; RESENDE, A. V.; HICKMANN, C.; AMARAL, T. A.; ALVES, M. E. B. Nitrogen dynamics in soils cultivated with maize and fertilized with pig slurry. Ambi-Agua, Taubaté, v. 7, n. 1, p. 9-23, 2012. (http://dx.doi.org/10.4136/ambi-agua.782)

Nutrient absorption efficiency has a direct relation with the morphological attributes of the crops rooting system (Horn et al., 2006). An increase in the root volume, when nutrient concentration is the same in the vicinity of the root surface, may lead to greater efficiency in nutrient absorption (Costa et al., 2002).

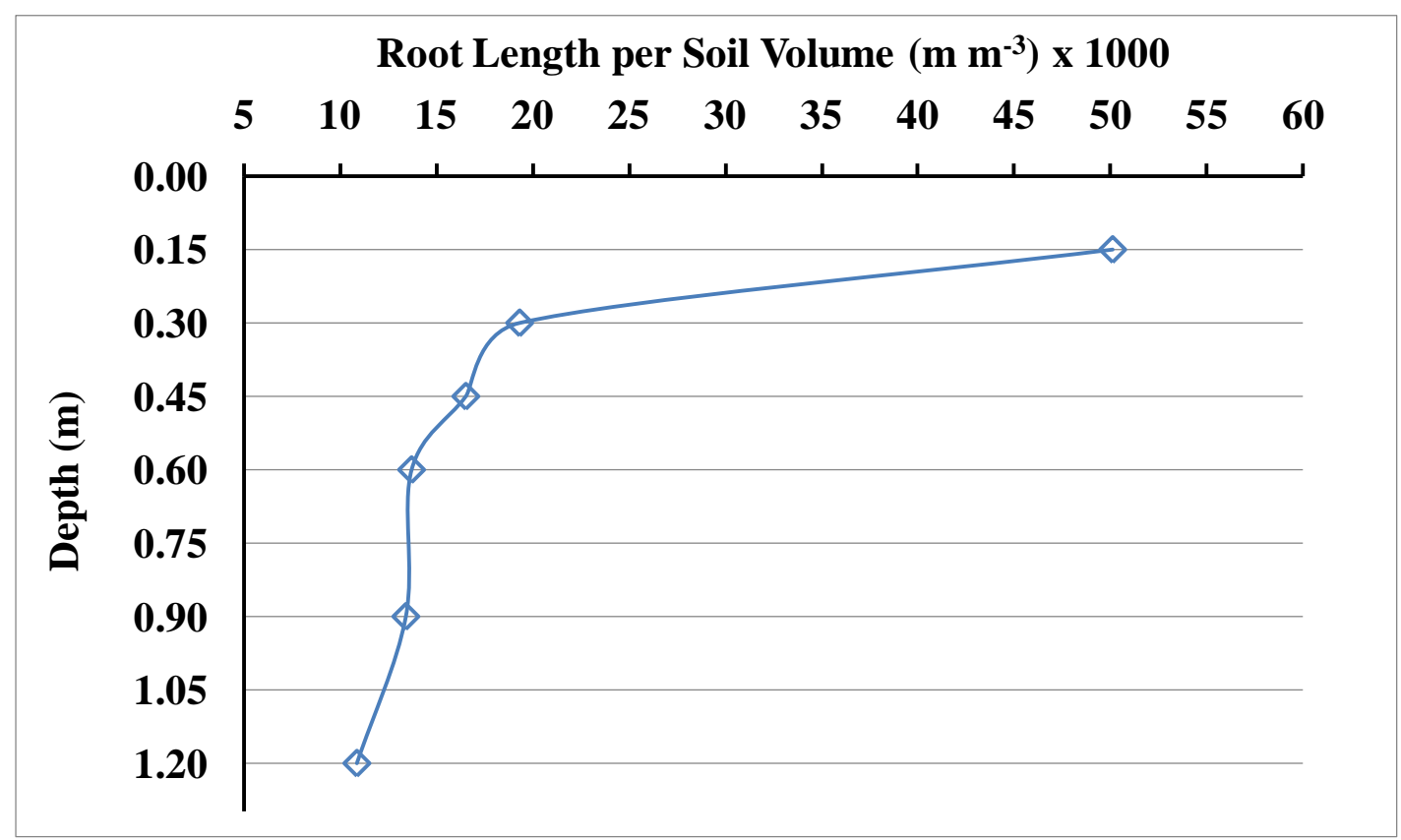

Figure 1. Distribution of root length (meters) per unit volume (cubic meters) of soil $\left(\mathrm{mm}^{-3}\right)$ x 1000 .

Considering the entire crop cycle, out of the $359.0 \mathrm{kgha}^{-1}$ of mineral nitrogen that entered the soil-plant system, the maize plant recovered $221.6 \mathrm{kgha}^{-1}(62 \%), 33.5 \mathrm{kgha}^{-1}$ (9\%) was leached, $51.1 \mathrm{kgha}^{-1}(14 \%)$ was retained in the 0 to $0.60 \mathrm{~m}$ soil layer, and $52.7 \mathrm{kgha}^{-1}(15 \%)$ was not recovered, meaning it was either volatilized or immobilized by the soil. The system outputs accounted for $306.3 \mathrm{kgha}^{-1}$ of mineral N. Similar results were obtained by Coelho et al. (1991), while Gava et al. (2006), studying soil-plant system nitrogen balance in a no-till maize field, observed that $44.5 \mathrm{kgha}^{-1}(45 \%)$ of $\mathrm{N}$-fertilizer was recovered by the plant, 34 $\mathrm{kgha}^{-1}(35 \%)$ was retained in the soil, and $20 \mathrm{kgha}^{-1}$ (20\%) was not recovered.

Duete et al. (2008), working with various sources of nitrogen fertilizer applied to a maize crop grown in an Oxisol, observed that, regardless of the source, the plants extracted an average of $130 \mathrm{kgha}^{-1}$. According Peoples et al. (2004), on average, $19 \%$ to $38 \%$ of the fertilizer applied to a conventional tillage maize cropping system remained in the soil after harvest, and $25 \%$ of the nitrogen was not recovered. The discrepancy between mineral $\mathrm{N}$ values observed in the studies is justified by differences in the ability of the soil to supply mineral $\mathrm{N}$, the amount of nitrogen added to the system, and the crop biomass production and $\mathrm{N}$ uptake capacity of the maize genotypes employed.

As might be expected in a production system that makes continued use of considerable doses of pig slurry as a supplementary source of fertilizer, the concentrations of nitrate, ammonium, and mineral nitrogen (nitrate + ammonium) observed in the soil profile were high early in the crop cycle (Figures 3, 4 e 5), decreasing with time. High initial mineral nitrogen content, between 55 and $92 \mathrm{kgha}^{-1}$ was observed in the 0 to $0.30 \mathrm{~m}$ layer, due to the slurry application on the soil surface and shallow mineral fertilizer incorporation at sowing. The highest rates of decrease in the mineral $\mathrm{N}$ over time were observed in the 0 to $0.30 \mathrm{~m}$ layer, where most of the maize rooting system is located (Figure 1). The $\mathrm{N}_{-} \mathrm{NO}_{3}{ }^{-}$content in the 0 to $0.30 \mathrm{~m}$ layer at 11 days after sowing (DAS) was $55.74 \mathrm{kgha}^{-1}$, as a result of the first side- 
SILVA, D. F; ANDRADE, C. L.T.; RESENDE, A. V.; HICKMANN, C.; AMARAL, T. A.; ALVES, M. E. B. Nitrogen dynamics in soils cultivated with maize and fertilized with pig slurry. Ambi-Agua, Taubaté, v. 7, n. 1, p. 9-23, 2012. (http://dx.doi.org/10.4136/ambi-agua.782)

dressing. This amount is within the range of 52.65 to $105.3 \mathrm{kgha}^{-1}$ considered critical, as reported by Rambo et al. (2007).

As a result of maize growth and development, the nitrate content in the 0 to $0.30 \mathrm{~m}$ layer decreased rapidly over time, reaching $12.16 \mathrm{kgha}^{-1}$ at $116 \mathrm{DAS}$. In turn, the reduction in nitrate content over time in the 0.60 to 1.20 m layer was slower. The amount of this element in that layer stabilized at $11.86 \mathrm{kgha}^{-1}$ at $102 \mathrm{DAS}$ (Figure 3). Nitrate content in the layers 0 to 0.30 and 0.60 to $1.20 \mathrm{~m}$ at the end of the crop cycle was below $52.65 \mathrm{kgha}^{-1}$, the critical level reported by Rambo et al. (2007).

The greatest reductions in nitrate, ammonium, and $\mathrm{N}$-mineral contents in the 0 to 0.30 and 0.30 to $0.60 \mathrm{~m}$ layers, where the largest roots volumes were concentrated (Figure 1), occurred between 0 to 102 DAS. This phase coincides with the period of the greatest nitrogen demand by a maize crop. França et al. (1994) showed that maize $\mathrm{N}$ uptake is most intense between 40 and 60 DAS.

Analyzing the nitrate content data of the 0.6 to $1.2 \mathrm{~m}$ soil layer (Figure 3), we observed a decreasing trend until 137 DAS, as expressed by the curve fitted to the values (Table 3). Certainly, the reduction in nitrate levels in this layer until 137 DAS was due to leaching, fostered by the intense rainfall regime that occurred in that period (Figure 2). A cumulative depth of $1163 \mathrm{~mm}$ of rain was recorded between 0 and 137 DAS, which corresponded to an average of 8.49 mmday $^{-1}$.

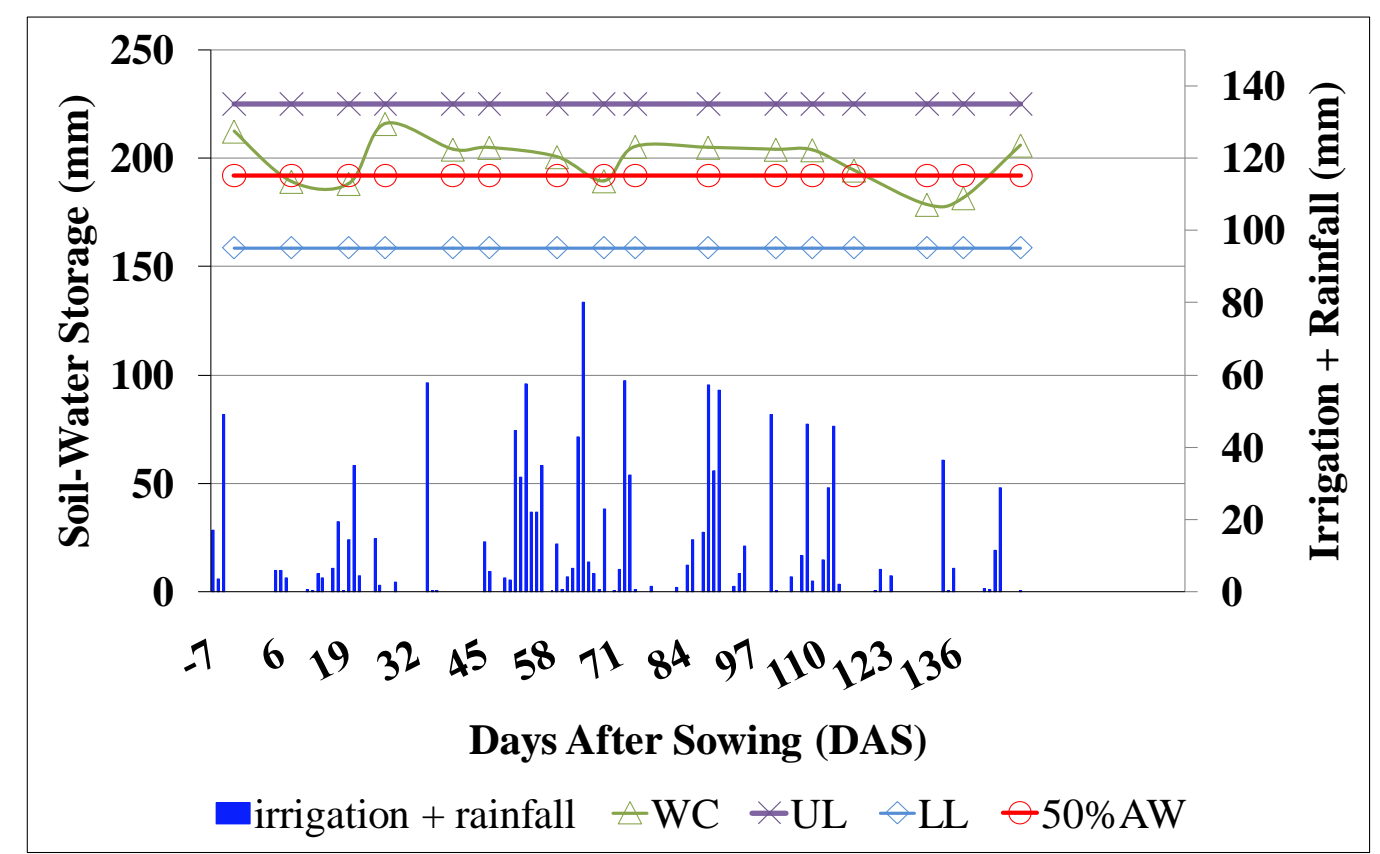

Figure 2. Water depths received by the crop (irrigation + rainfall), soil-water stored in the 0 to $0.60 \mathrm{~m}$ layer at the water content (WC) and upper (UL) and lower (LL) limit of available water and at $50 \%$ of available water (AW) for the 2008/2009 crop season.

The nitrate accumulation in the 0.6 to $1.2 \mathrm{~m}$ layer, relative to other layers, was high at 102 to 137 DAS period, since the crop was at its final grain-filling phase and the nitrogen demand drops. In addition, less nitrate leaching occurs as a consequence of no irrigation and less rain received in this stage (Figure 2). The mineralization of crop residues and of current crop abscised leaves can also contribute to nitrogen supply to the soil, and when there is no plant uptake, this element tends to leach and accumulate in the deep layers, where its adsorption is greater (Torres et al., 2005). 
SILVA, D. F; ANDRADE, C. L.T.; RESENDE, A. V.; HICKMANN, C.; AMARAL, T. A.; ALVES, M. E. B. Nitrogen dynamics in soils cultivated with maize and fertilized with pig slurry. Ambi-Agua, Taubaté, v. 7, n. 1, p. 9-23, 2012. (http://dx.doi.org/10.4136/ambi-agua.782)

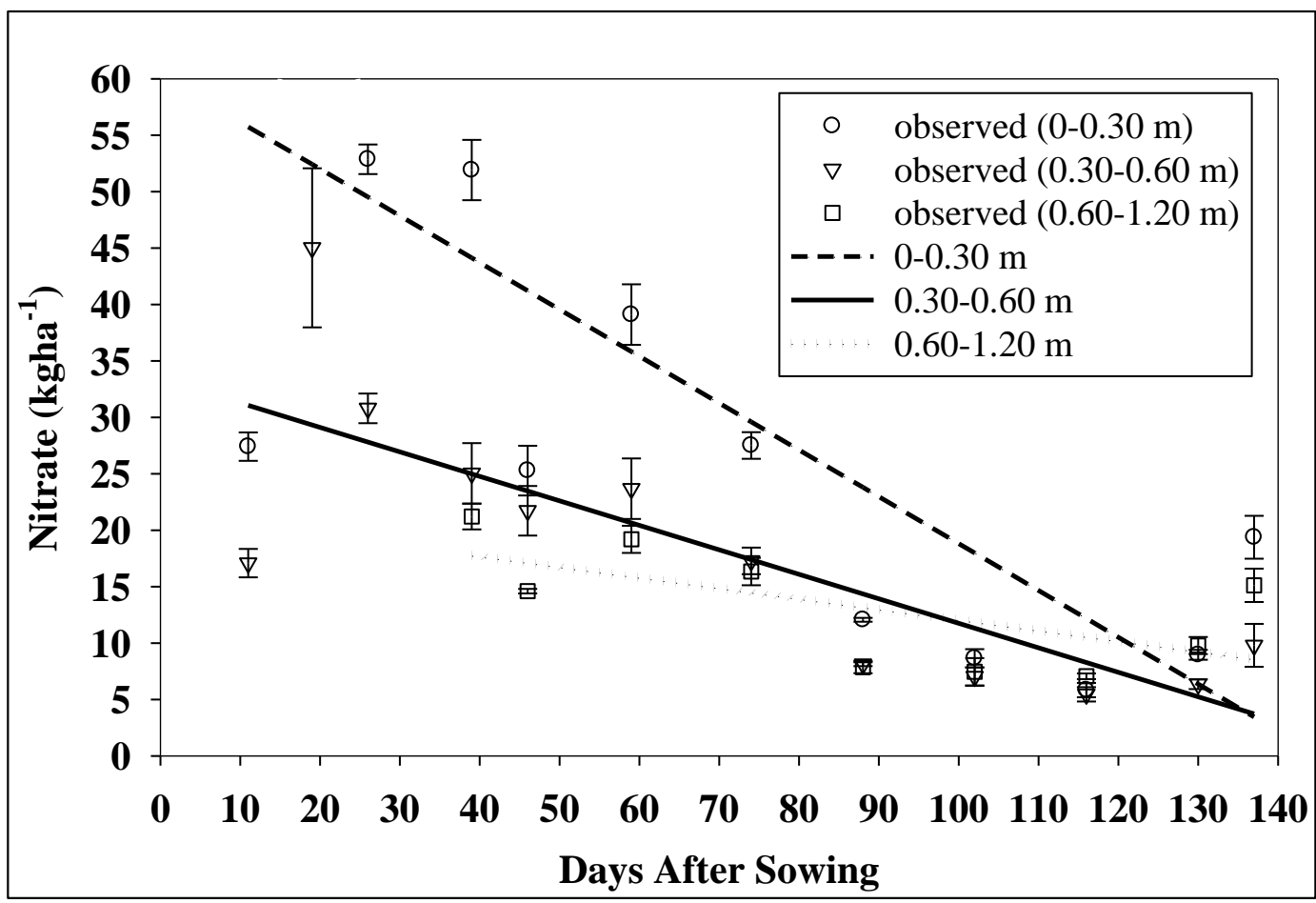

Figure 3. Soil nitrate content in the layers 0 to $0.30,0.30$ to 0.60 , and 0.60 to $1.20 \mathrm{~m}$, along the cycle of a maize crop, grown in an Oxisol managed with pig slurry and with mineral fertilization. Vertical bars are the standard error above and below the average.

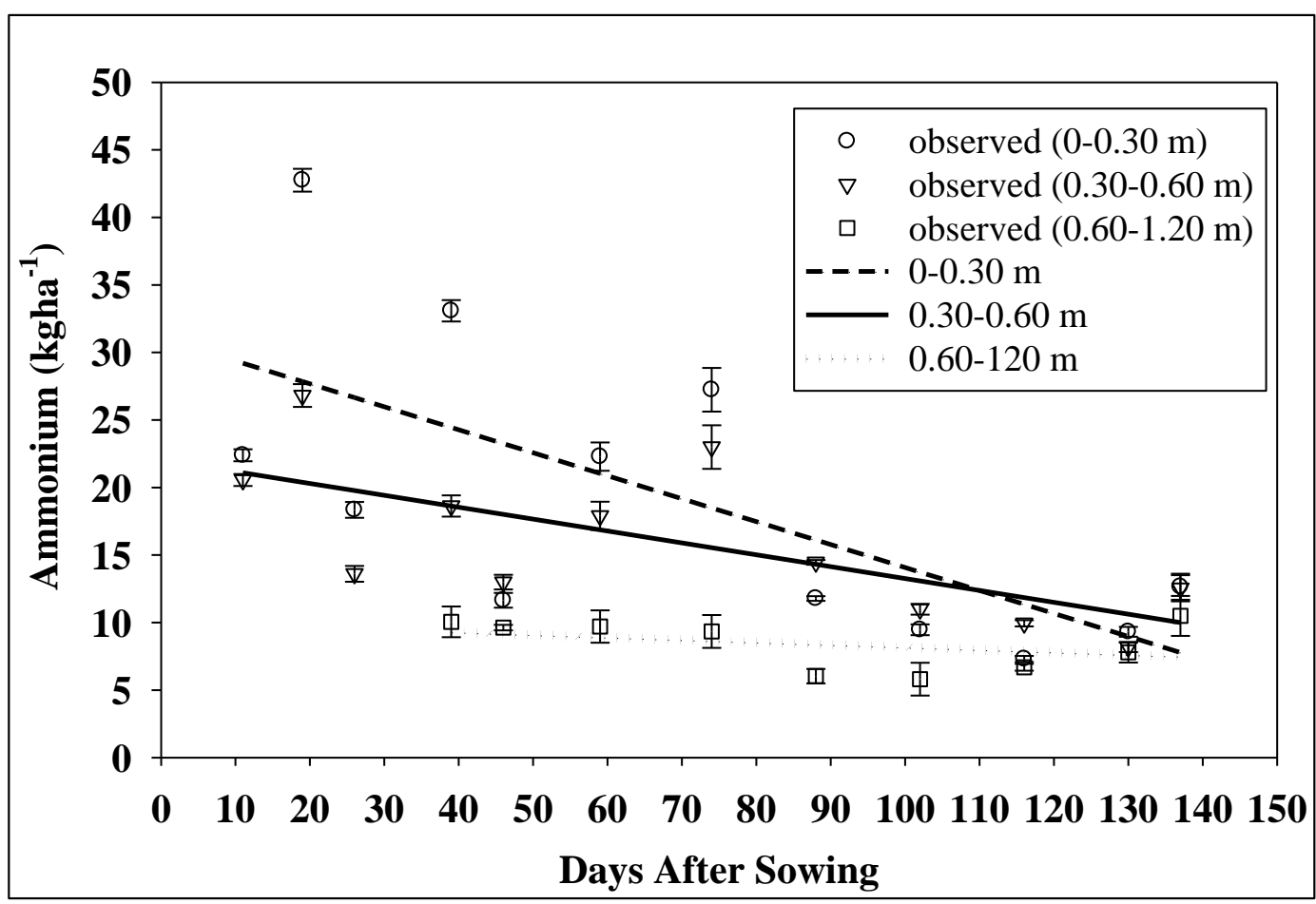

Figure 4. Soil ammonium content in the layers 0 to $0.30,0.30$ to 0.60 , and 0.60 to 1.20 $\mathrm{m}$, along the cycle of a maize crop, grown in an Oxisol managed with pig slurry and with mineral fertilization. Vertical bars are the standard error above and below the average. 
SILVA, D. F; ANDRADE, C. L.T.; RESENDE, A. V.; HICKMANN, C.; AMARAL, T. A.; ALVES, M. E. B. Nitrogen dynamics in soils cultivated with maize and fertilized with pig slurry. Ambi-Agua, Taubaté, v. 7, n. 1, p. 9-23, 2012. (http://dx.doi.org/10.4136/ambi-agua.782)

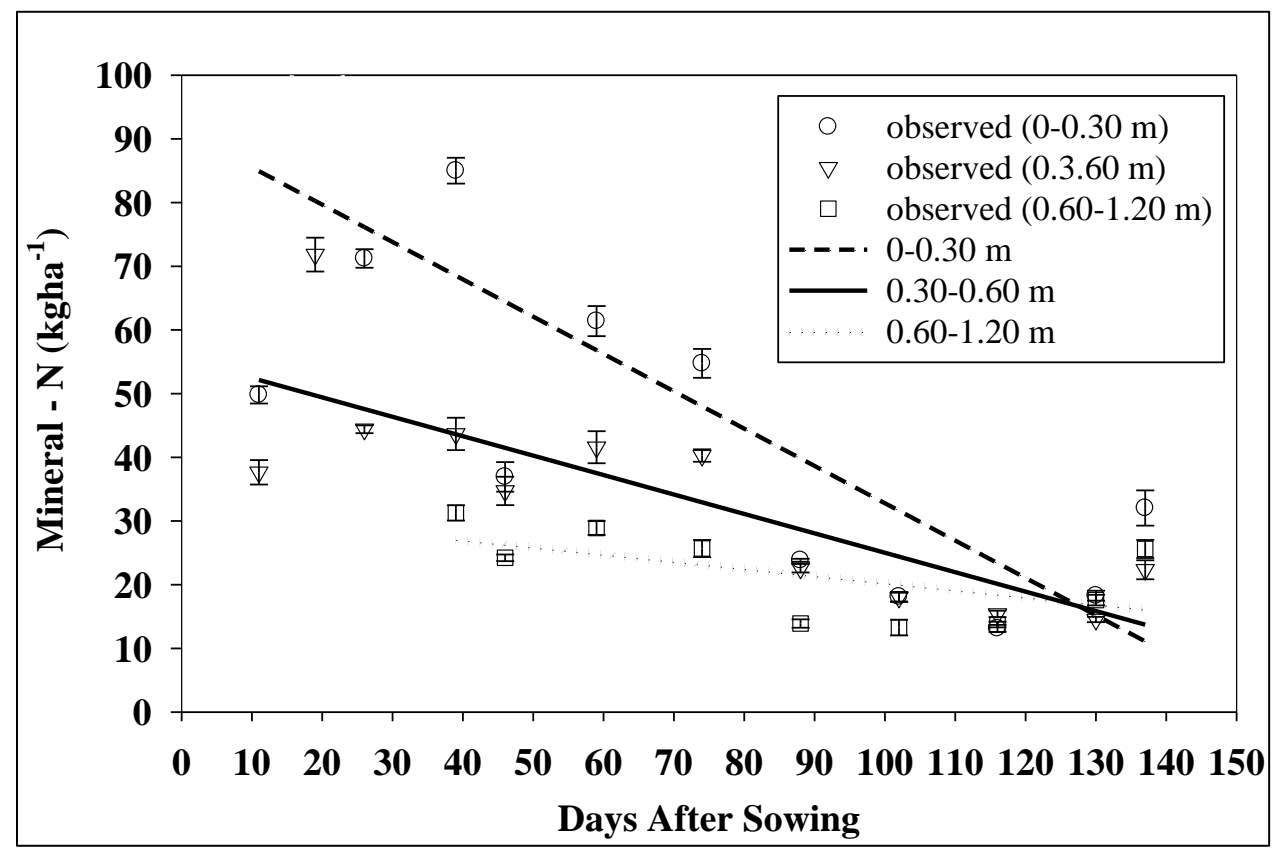

Figure 5. Soil mineral-N content in the layers 0 to $0.30,0.30$ to 0.60 , and 0.60 to $1.20 \mathrm{~m}$, along the cycle of a maize crop, grown in an Oxisol managed with pig slurry and with mineral fertilization. Vertical bars are the standard error above and below the average.

Table 3. Linear regression equations fitted to nitrate $\left(\mathrm{N}^{-N_{3}}{ }^{-}\right)$, ammonium $\left(\mathrm{N}^{-} \mathrm{NH}_{4}{ }^{+}\right)$, and to mineral nitrogen (mineral-N) as a function of days after sowing (DAS).

\begin{tabular}{|c|c|c|c|}
\hline Nutrients & Layer $(\mathbf{m})$ & Equation & $\mathbf{R}^{2}(\%)$ \\
\hline \multirow{3}{*}{$\mathbf{N}-\mathrm{NO}_{3}^{-}$} & $0-0.30$ & $\mathrm{~N}^{-\mathrm{NO}_{3}}{ }^{-}=-0.415 \mathrm{DAS}^{*}+60.309$ & 52.60 \\
\hline & $0.30-0.60$ & $\mathrm{~N}-\mathrm{NO}_{3}{ }^{-}=-0.217 \mathrm{DAS}^{*}+33.455$ & 63.91 \\
\hline & $0.60-1.20$ & $\mathrm{~N}^{-\mathrm{NO}_{3}}{ }^{-}=-0.0938 \mathrm{DAS}^{*}+21.430$ & 40.26 \\
\hline \multirow{3}{*}{$\mathbf{N}-\mathrm{NH}_{4}^{+}$} & $0-0.30$ & $\mathrm{~N}-\mathrm{NH}_{4}{ }^{+}=-0.170 \mathrm{DAS}^{*}+31.070$ & 46.84 \\
\hline & $0.30-0.60$ & $\mathrm{~N}-\mathrm{NH}_{4}{ }^{+}=-0.088 \mathrm{DAS}^{*}+22.060$ & 47.91 \\
\hline & $0.60-1.20$ & $\mathrm{~N}^{-\mathrm{NH}_{4}}{ }^{+}=-0.018 \mathrm{DAS}^{*}+10.013$ & 13.06 \\
\hline \multirow{3}{*}{ mineral-N } & $0-0.30$ & mineral- $\mathrm{N}=-0.586 \mathrm{DAS}^{*}+91.378$ & 53.31 \\
\hline & $0.30-0.60$ & mineral- $\mathrm{N}=-0.305 \mathrm{DAS}^{*}+55.514$ & 66.50 \\
\hline & $0.60-1.20$ & mineral- $\mathrm{N}=-0.112 \mathrm{DAS}^{*}+31.445$ & 33.20 \\
\hline
\end{tabular}

* significant at $5 \%$ probability by t test.

The dynamic of $\mathrm{N}^{-} \mathrm{NH}_{4}{ }^{+}$(Figure 4) in the soil profile showed a pattern similar to $\mathrm{N}-\mathrm{NO}_{3}{ }^{-}$ (Figure 3), although ammonium content in the soil profile, and reduction rates over time, were lower. With the crop growth and development, $\mathrm{N}$ uptake (Figure 6) increased and, therefore, the $\mathrm{N}-\mathrm{NH}_{4}{ }^{+}$quantities presented in the soil profile were reduced (Figure 4). Concomitantly, 
SILVA, D. F; ANDRADE, C. L.T.; RESENDE, A. V.; HICKMANN, C.; AMARAL, T. A.; ALVES, M. E. B. Nitrogen dynamics in soils cultivated with maize and fertilized with pig slurry. Ambi-Agua, Taubaté, v. 7, n. 1, p. 9-23, 2012. (http://dx.doi.org/10.4136/ambi-agua.782)

ammonium nitrification occurred, turning it into $\mathrm{N}^{-\mathrm{NO}_{3}}{ }^{-}$, which is the main source of nitrogen assimilated by crops, although it is more readily leachable. The low $\mathrm{pH}$ and CEC values of soil subsurface layers (Table 1) favored leaching of that cation below the root zone. As occurred with the $\mathrm{N}-\mathrm{NO}_{3}{ }^{-}$, the $\mathrm{N}-\mathrm{NH}_{4}{ }^{+}$content stabilized around $7.88 \mathrm{kgha}^{-1}$ at $116 \mathrm{DAS}$ (Figure 4).

It can be seen in Figure 4 and in the equation in Table 3 that at 11 DAS the highest N$\mathrm{NH}_{4}{ }^{+}$values were observed in the upper layer, while at 110 DAS the highest concentrations were measured at the 0.30 to $0.60 \mathrm{~m}$ layer, indicating that this element moved vertically in the soil profile, possibly due to the ammonification of organic $\mathrm{N}$ contributing to the increase of $\mathrm{N}-\mathrm{NH}_{4}{ }^{+}$content in that layer. Gonçalves et al. (2001) and Oliveira et al. (2001), studying the ammonium behavior in the soil, observed the presence of this element at the subsurface layers, thus demonstrating its movement in tropical soils. Cabezas and Souza (2008), in an trial to evaluate the combined use of gypsum and urea in a maize crop observed a higher

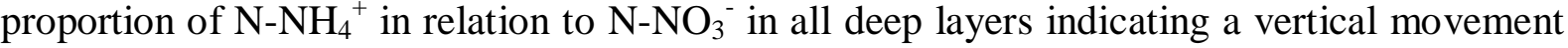
of ammonium favored by the presence of gypsum. According to Scherer et al. (2010), organic fertilizers have, in general, a greater residual effect on the soil as compared to mineral fertilizers. This pattern is explained by the slow mineralization of organic compounds making the nutrients available in a longer time frame. Thus these nutrients are less subject to chemical reactions in the soil unlike the mineral fertilizers.

The content of mineral $\mathrm{N}$ in the cultivated soil decreases with depth and over time as can be seen in Figure 5, following the same pattern of nitrate and ammonium. Cardoso Neto et al. (2006), evaluating different nitrogen sources, found that the highest concentrations of mineral $\mathrm{N}$ was observed in the topsoil following a decrease in concentrations with depth; the same occurring with ammonium and nitrate. Similar results were also found by Silva et al. (2005) and Ceretta et al. (2002).

The $\mathrm{N}^{-\mathrm{NO}_{3}}{ }^{-}$content at layers 0 to $0.3,0.3$ to 0.6 and 0.6 to $1.2 \mathrm{~m}$ of the soil profile under the native Cerrado was $31.1,30.9$ and $48.7 \mathrm{kgha}^{-1}$, respectively. The $\mathrm{N}_{-} \mathrm{NH}_{4}{ }^{+}$content were $60.1,34.5$ and $65.8 \mathrm{kgha}^{-1}$ in the same layers. Both nitrate and ammonium quantities were higher than those observed in the cultivated area (Figures 3 and 4). This behavior is due to the constant recycling of nutrients observed in the natural environment which is in a dynamic equilibrium.

In the cultivated soil, the process of soil organic matter decomposition becomes faster because of the acidity corrections and constant soil fertilization providing favorable conditions for the development of nitrifying microorganisms. Adding to this, the crop nutrient uptake caused a decrease in soil $\mathrm{N}$ content.

It can be seen in Figure 6 that the maximum accumulation of nitrogen was $132 \mathrm{kgha}^{-1}$ in the grain and $240 \mathrm{kgha}^{-1}$ in the aboveground maize biomass. The $\mathrm{N}$ uptake by a maize crop with a potential to yield 3 to $12 \mathrm{tha}^{-1}$ is in the range of 84 to $336 \mathrm{kgha}^{-1}$ (Cantarella, 2007). We noted that the $\mathrm{N}$ accumulation observed in this study is in the range considered normal for the maize crop.

From 21 to 90 DAS, $\mathrm{N}$ was absorbed by maize crop at an average rate of approximately $3.28 \mathrm{kgha}^{-1}$ day $^{-1}$. Absorption was more intense from 21 to 40 DAS, when it reached an average rate of $6.0 \mathrm{kgha}^{-1} \mathrm{day}^{-1}$ (Figure 6). Despite the nutritional requirements being lower in the early growth stages, research indicates that high $\mathrm{N}$ concentrations in the rooting zone are beneficial in promoting a rapid initial plant growth and in increasing yield (Varvel et al., 1997). According to Arnon (1975), nitrogen requirements vary considerably with the different maize crop stages. A minimal amount is required in the early stages, rising with increasing growth rate and reaching a peak from flowering to early grain formation phases. 
SILVA, D. F; ANDRADE, C. L.T.; RESENDE, A. V.; HICKMANN, C.; AMARAL, T. A.; ALVES, M. E. B. Nitrogen dynamics in soils cultivated with maize and fertilized with pig slurry. Ambi-Agua, Taubaté, v. 7, n. 1, p. 9-23, 2012. (http://dx.doi.org/10.4136/ambi-agua.782)

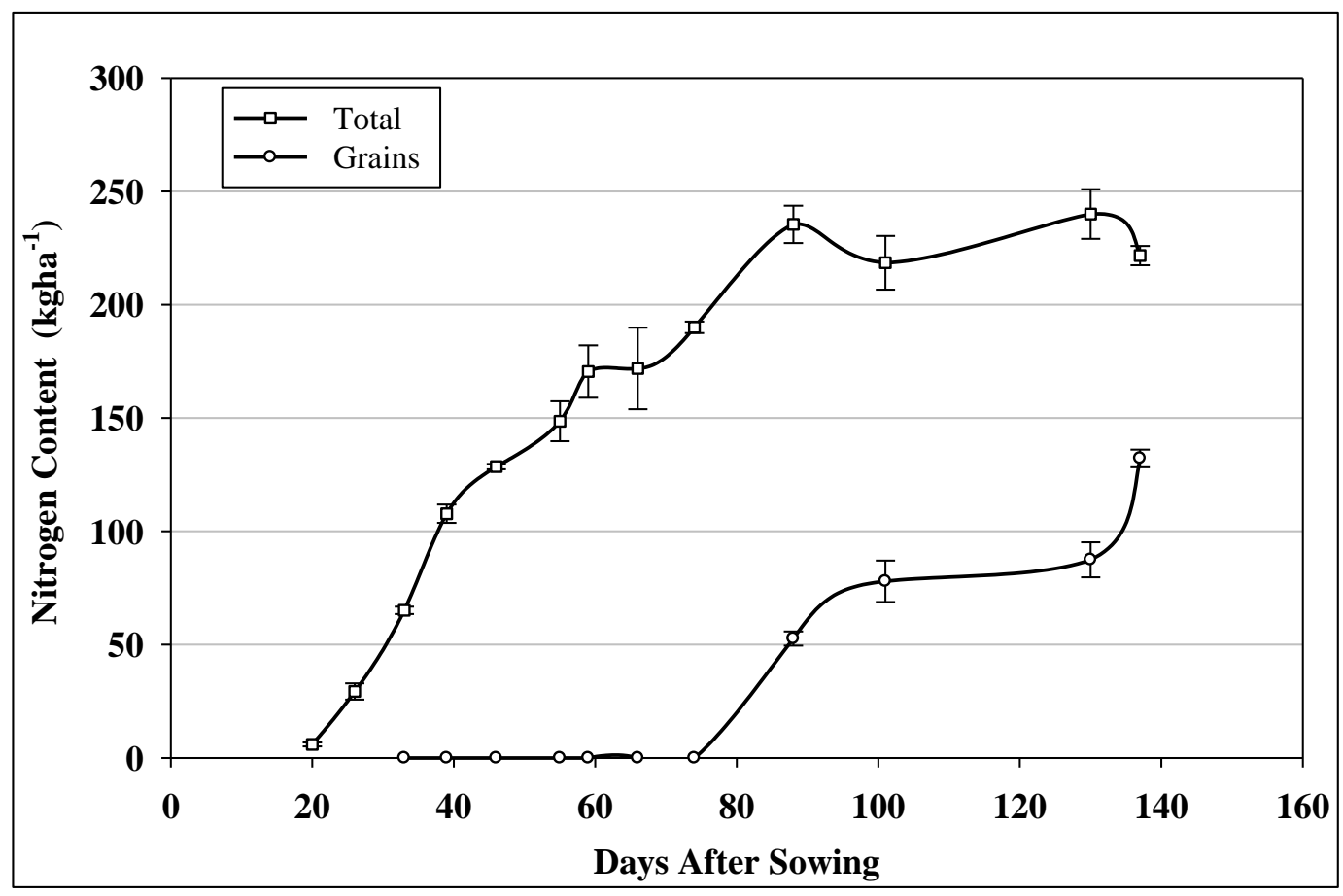

Figure 6. Nitrogen content in the biomass and grain along the maize crop cycle. Vertical bars are standard error above and below the average.

The average crop yield was $10.817 \mathrm{kgha}^{-1}$ of grain with $13 \%$ humidity, which is a high yield as compared to the average figure for the Minas Gerais State, which is $5.118 \mathrm{kgha}^{-1}$ (Agrianual, 2011). The average yield of the DKB 390YG hybrid varies from 8.414 to 8.659 $\mathrm{kgha}^{-1}$ (DEKALB, 2011). Evans et al. (1977), studying the performance of maize fertilized with pig slurry at a rate of 636 tha $^{-1}$ (fresh weight) for two successive years and monitored for two more years, observed that the average grain yield was $7.100 \mathrm{kgha}^{-1}$, whereas for mineral fertilization treatments this value was $6.880 \mathrm{kgha}^{-1}$. In studies reported by Konzen and Alvarenga (2002), the yield of a trial in which maize was fertilized with pig slurry was between 5.200 and $7.600 \mathrm{kgha}^{-1}$.

\section{CONCLUSIONS}

The crop was able to recover $62 \%$ of the mineral nitrogen that entered the soil-plant system, and we estimated that $9 \%$ leached as nitrate and, to a lesser amount, as ammonium.

The maximum average content of nitrate and ammonium in the 0 to $0.3 \mathrm{~m}$ layer was 92 $\mathrm{kgha}^{-1}$ and $43 \mathrm{kgha}^{-1}$, respectively, in the early crop stage, and a minimum of $5.8 \mathrm{kgha}^{-1}$ of nitrate and $9.0 \mathrm{kgha}^{-1}$ of ammonium, at the end of the crop cycle.

The nitrate content at the 0.60 to $1.20 \mathrm{~m}$ soil layer at the end of the crop cycle remains below the values observed in the native Cerrado, indicating that the current agricultural use of the land poses no additional risk of nitrate accumulation and leaching.

\section{ACKNOWLEDGMENTS}

To CNPq, for the financial support given to projects $\mathrm{n}^{\circ} 559065 / 2008-6$ and $\mathrm{n}^{\circ}$ 476169/2008-9. To Embrapa's Maize and Sorghum staff for help with collecting and analyzing the data. To the farmer who allowed the development of this study on his farm. 
SILVA, D. F; ANDRADE, C. L.T.; RESENDE, A. V.; HICKMANN, C.; AMARAL, T. A.; ALVES, M. E. B. Nitrogen dynamics in soils cultivated with maize and fertilized with pig slurry. Ambi-Agua, Taubaté, v. 7, n. 1, p. 9-23, 2012. (http://dx.doi.org/10.4136/ambi-agua.782)

\section{REFERENCES}

AGRIANUAL - Anuário da agricultura brasileira. São Paulo: Instituto FNP, 2011. 482 p.

AMADO, T. J. C.; MIELNICZUK, J.; AITA, C. Recomendação de adubação nitrogenada para o milho no RS e SC adaptada ao uso de culturas de cobertura do solo, sob plantio direto. Revista Brasileira de Ciência do Solo, Viçosa, MG, v. 26, n. 1, p. 241-248, 2002.

ARNON, I. Mineral nutrition of maize. Bern: International Potash Institute, 1975. 452 p.

BORTOLINI, C. G.; SILVA, P. R. F.; ARGENTA, G.; FORSTHOFER, E. L. Sistemas de aplicação de nitrogênio e seus efeitos sobre o acúmulo de $\mathrm{N}$ na planta de milho. Revista Brasileira de Ciência do Solo, Viçosa, MG, v. 26, n. 3, p. 361-366, 2000.

BRASIL. Ministério da Agricultura, Pecuária e Abastecimento. Programa ABC. Agricultura de baixo carbono: plante sustentabilidade, colha resultados. Brasília, 2010. Disponível em: <http://www.agricultura.gov.br/abc>. Acesso em: 22 set. 2011.

CABEZAS, W. A. R. L.; SOUZA, M. A. Volatilização de amônio, lixiviação de nitrogênio e produtividade de milho em resposta à aplicação de mistura de uréia com sulfato de amônio ou com gesso agrícola. Revista Brasileira de Ciência do Solo, Viçosa, MG, v. 32 , n. 4, p. 2331-2342, 2008.

CANTARELlA, H. Nitrogênio. In: NOVAIS, R. F.; ALVAREZ V.V. H.; BARROS, N. F. de; FONTES, R. L. F.; CANTARUTTI, R. B.; NEVES, J. C. L. (Ed.). Fertilidade do solo. Viçosa, MG: Sociedade Brasileira de Ciência do Solo, 2007. p. 375-470.

CARDOSO NETO, F.; GUERRA, H. O. C.; CHAVES, G. L. H. Nitrogênio residual em solo adubado com diferentes fontes e intervalos de aplicação de nitrogênio. Revista Caatinga, Mossoró, v. 19, n. 2, p. 161-168, 2006.

CERETTA, C. A. Características químicas de solo sob aplicação de dejeto líquido de suínos em pastagem natural. Pesquisa Agropecuária Brasileira, Brasília, v. 38, n. 6, p. 729735, 2003.

CERETTA, C. A.; BASSO, C. J.; FLECHA, A. M. T.; PAVINATO, P. S.; VIEIRA, F. C. B.; MAI, M. E. M. Manejo da adubação nitrogenada na sucessão aveia preta/milho, no sistema plantio direto. Revista Brasileira de Ciência do Solo, Viçosa, MG, v. 16, n. 1, p. 163-171, 2002.

COElHO, A. M.; FRANÇA, G. E.; BAHIA, A. F. C.; GUEDES, G. A. A. Balanço de nitrogênio $(15 \mathrm{~N})$ em um Latossolo Vermelho escuro, sob vegetação de cerrado, cultivado com milho. Revista Brasileira de Ciência do Solo, Viçosa, MG, v. 15, n. 2, p. 187-193, 1991.

COSTA, C.; DWYER, L. M.; ZHOU, X.; DUTILlEUL, P.; HAMEL, C.; REID, L. M. et al. Root morphology of contrasting maize genotypes. Agronomy Journal, Madison, v. 94, n. 1, p. 96-101, 2002. http://dx.doi.org/10.2134/agronj2002.0096

DEKALB. Semente híbrida de milho safrinha 2007 DKB 390. Disponível em: <http://www.dekalb.com.br/produto_milho_safrinha.aspx?id=34>. Acesso em: 26 abr. 2011. 
SILVA, D. F; ANDRADE, C. L.T.; RESENDE, A. V.; HICKMANN, C.; AMARAL, T. A.; ALVES, M. E. B. Nitrogen dynamics in soils cultivated with maize and fertilized with pig slurry. Ambi-Agua, Taubaté, v. 7, n. 1, p. 9-23, 2012. (http://dx.doi.org/10.4136/ambi-agua.782)

DUETE, R. R. C.; MURAOKA, T.; SILVA, E. C.; TRIVElin, P. C. O.; AMBROSANO, E. J. Manejo da adubação nitrogenada e utilização nitrogênio (15N) pelo milho em Latossolo Vermelho. Revista Brasileira Ciência do Solo, Viçosa, MG, v. 32, n. 1, p. 161-171, 2008.

DYNIA, J. F.; SOUZA, M. D.; BOEIRA, R. C. Lixiviação de nitrato em Latossolo cultivado com milho após aplicações sucessivas de lodo de esgoto. Pesquisa Agropecuária Brasileira, Brasília, v. 41, n. 5, p. 855-862, 2006.

EMBRAPA. Centro Nacional de Pesquisa de Solos. Manual de métodos de análise de solo. 2. ed. Rio de Janeiro, 1997. 212 p. (EMBRAPA- CNPS. Documento, 1).

EVANS, S. D.; GOODRICH, P. R.; MUNTER, R. C. Effects of solid and liquid beef manure and liquid hog manure on soil characteristics and on growth, yield and decomposition of corn. Journal Environ Quality, Madison, v. 6, n. 2, p. 361-368, 1977. http://dx.doi.org/10.2134/jeq1977.00472425000600040006x

FERREIRA, D. F. Manual do sistema SISVAR para análise estatística. Lavras: UFLA, 2000. 63 p.

FRANÇA, G. E.; COELHO, A. M.; RESENDE, M.; BAHIA FILHO, A. F. C. Parcelamento da adubação nitrogenada em cobertura na cultura do milho irrigado. In: EMBRAPA. Centro Nacional de Pesquisa de Milho e Sorgo. Relatório técnico anual do Centro Nacional de Pesquisa de Milho e Sorgo: 1992-1993. Sete Lagoas, 1994. p. 28-29.

GAVA, G. J. C.; TRIVELIN, P. C. O.; OLIVEIRA, M. W.; HEINRICHS, R.; SILVA, M. A. Balanço do nitrogênio da uréia $\left({ }^{15} \mathrm{~N}\right)$ no sistema solo-planta na implantação da semeadura direta na cultura do milho. Bragantia, Campinas, v. 65, n. 3, p. 477-486, 2006.

GIACOMINI, S. J.; AITA, C. Cama sobreposta e dejetos líquidos de suínos como fonte de nitrogênio ao milho. Revista Brasileira de Ciência do Solo, Viçosa, MG, v. 32, n. 1, p. 195-205, 2008.

GIACOMINI, S. J.; AITA, C.; JANTALIA, C. P.; URQUIAGA, S.; SANTOS, G. F. dos. Imobilização do nitrogênio amoniacal de dejetos líquidos de suínos em plantio direto e preparo reduzido do solo. Revista Brasileira de Ciência do Solo, Viçosa, MG, v. 33, n. 1, p. 41-50, 2009.

GONÇALVES, J. L. M.; MENDES, K. C. F. S.; SASAKI, C. M. Mineralização de nitrogênio em ecossistemas florestais naturais e implantados do Estado de São Paulo. Revista Brasileira de Ciência do Solo, Viçosa, v. 25, n. 3, p. 601-616, 2001.

HORN, D.; ERNANI, P. R.; SANGOI, L.; SCHWEITZER, C.; CASSOL, P. C. Parâmetros cinéticos e morfológicos da absorção de nutrientes em cultivares de milho com variabilidade genética contrastante. Revista Brasileira de Ciência do Solo, Viçosa, MG, v. 30, n. 2, p. 77-85, 2006.

IVO, W. M. P.; MIELNICZUK, J. Influência da estrutura do solo na distribuição e na morfologia do sistema radicular do milho sob três métodos de preparo. Revista Brasileira de Ciência do Solo, Viçosa, MG, v. 23, n. 1, p. 135-143, 1999. 
SILVA, D. F; ANDRADE, C. L.T.; RESENDE, A. V.; HICKMANN, C.; AMARAL, T. A.; ALVES, M. E. B. Nitrogen dynamics in soils cultivated with maize and fertilized with pig slurry. Ambi-Agua, Taubaté, v. 7, n. 1, p. 9-23, 2012. (http://dx.doi.org/10.4136/ambi-agua.782)

KONZEN, E. A. Fertilização de lavoura e pastagem com dejetos de suínos e cama de aves. Sete Lagoas: Embrapa Milho e Sorgo, 2003. 3 p. (Embrapa Milho e Sorgo. Circular Técnica, 31). Disponível em: <http:// http://ainfo.cnptia.embrapa.br/ digital/bitstream/CNPMS/16184/1/Circ_31.pdf>. Acesso em: 26 abril 2011.

KONZEN, E. A.; ALVARENGA, R. C. Monitoramento ambiental do uso de dejetos líquidos de suínos como insumo na agricultura: efeito de doses na produtividade de milho. Revista Brasileira de Ciência do Solo, Viçosa, MG, v. 2, n. 3, p. 123-131, 2002.

NOGUEIRA, A. R. A.; SOUZA, G. B. Manual de laboratórios: solo, água, nutrição vegetal, nutrição animal e alimentos. In: PRIMAVESI, A. C.; ANDRADE, A. G.; ALVES, B. J. R.; ROSSO, C.; BATISTA, E. M.; PRATES, H. T. et al. Métodos de análise de solo. São Carlos: Embrapa Pecuária Sudeste, 2005. p. 67-130.

OLIVEIRA, F. C. Percolação de nitrato em Latossolo Amarelo Distrófico afetada pela aplicação de composto de lixo urbano e adubação mineral. Revista Brasileira de Ciência do Solo, Viçosa, MG, v. 25, n. 3, p. 731-741, 2001.

OLIVEIRA, J. R. A. de; VILELA, L.; AYARZA, M. A. Adsorção de nitrato em solos de cerrado do Distrito Federal. Pesquisa Agropecuária Brasileira, Brasília, v. 35, n. 6, p. 1199-1205, 2000.

PEOPLES, M. B.; BOYER, E. W.; GOULDING, K. W. T.; HEFFER, P.; OCHWOH, V. A.; VANLAUWE, B. et al. Pathways of nitrogen loss and their impacts on human health and the environment. In: MOSIER, A.; SYERS, J. K.; FRENEY, J. R. (Ed.). Agriculture and the nitrogen cycle: assessing the impacts of fertilizer use on food production and the environment. Washington: Island Press, 2004. p. 53-69. (SCOPE report, 65).

RAMBO, L.; SILVA, P. R. F.; BAYER, C; ARGENTA, G.; STRIEDER, M. L.; SILVA, A. A. Testes de nitrato no solo como indicadores complementares da disponibilidade de nitrogênio no solo para o milho. Revista Brasileira de Ciência do Solo, Viçosa, MG, v. 31, n. 1, p. 731-738, 2007.

RAMBO, L.; SILVA, P. R. F.; ARGENTA, G.; BAYER, C. Testes de nitrato no solo como indicadores complementares no manejo da adubação nitrogenada em milho. Ciência Rural, Santa Maria, v. 34, n. 4, p. 1279-1287, 2004.

RIBEIRO, P. E. de A. Implementação de análise de nitrogênio total em solo pelo método de Dumas. Sete Lagoas: Embrapa Milho e Sorgo, 2010. 26 p. (Embrapa Milho e Sorgo. Documentos, 115).

SCHERER, E. E.; NESI, C. N.; MASSOTTI, Z. Atributos químicos do solo influenciados por sucessivas aplicações de dejetos suínos em áreas agrícolas de Santa Catarina. Revista Brasileira de Ciência do Solo, Viçosa, MG, v. 34, n. 2, p. 1375-1383, 2010.

SEIDEL, E. P.; GONÇALVES JUNIOR, A. C.; VANIN, J. P.; STREY, L.; SCHWANTES, D.; NACKE, H. Aplicação de dejetos de suínos na cultura do milho cultivado em sistema de plantio direto. Acta Scientiarum Technology, Maringá, v. 32, n. 2, p. 113$117,2010$. 
SILVA, D. F; ANDRADE, C. L.T.; RESENDE, A. V.; HICKMANN, C.; AMARAL, T. A.; ALVES, M. E. B. Nitrogen dynamics in soils cultivated with maize and fertilized with pig slurry. Ambi-Agua, Taubaté, v. 7, n. 1, p. 9-23, 2012. (http://dx.doi.org/10.4136/ambi-agua.782)

SILVA, E. C.; BUZETTI, S.; GUIMARÃES, G. L.; LAZARINI, E.; SÁ, M. E. Doses e épocas de aplicação de nitrogênio na cultura do milho em plantio direto sobre Latossolo Vermelho. Revista Brasileira de Ciência do Solo, Viçosa, MG, v. 29, n. 3, p. 353-362, 2005.

TORRES, J. L. R.; PEREIRA, M. G.; ANDRIOLI, I.; POLIDORO, J. C.; FABIAN, A. J. Decomposição e liberação de nitrogênio de resíduos culturais de plantas de cobertura em um solo de cerrado. Revista Brasileira de Ciência do Solo, Viçosa, MG, v. 29, n. 3, p. 609-618, 2005.

VARVEL, G. E.; SCHPERS, J. S.; FRANCIS, D. D. Ability for in-season correction of nitrogen deficiency in corn using chlorophyll meters. Soil Science Society of America Journal, Madison, v. 61, n. 4, p. 1233-1239, 1997.

WHITE, R. E. Leaching. In: WILSON, J. R. Advances in nitrogen cycling in agricultural ecosystems. Wallingford: CAB International, 1987. p. 193-211. 